\title{
Defining the Field of Police Psychology: Core Domains \& Proficiencies
}

\author{
Gary Aumiller • Dave Corey • Scott Allen • \\ JoAnne Brewster • Michael Cuttler • Herbert Gupton • \\ Audrey Honig
}

Published online: 21 May 2008

(C) Springer Science + Business Media, LLC 2008

\section{Erratum to: J Police Crim Psych}

\section{DOI 10.1007/s11896-007-9013-4}

The article in the Fall Issue 22 (2) titled "Defining the Field of Police Psychology: Core Domains \& Proficiencies" (10.1007/s11896-007-9013-4) should have included the following contributing authors: Aumiller, Gary; Corey, Dave; Allen, Scott; Brewster, JoAnne; Cuttler, Michael; Gupton, Herbert; and Honig, Audrey. Our apologies to the authors inadvertently omitted in the original printing.

The online version of this article is available at http://dx.doi.org/ 10.1007/s11896-007-9013-4.

\section{G. Aumiller $(\bowtie)$}

Police and Forensic Psychologist

e-mail: sineater@msn.com

D. Corey

Consulting and Forensic Psychologist

S. Allen

Miami-Dade Police Department

J. Brewster

James Madison University
M. Cuttler

Law Enforcement Services, Inc.

H. Gupton

Honolulu Police Department

A. Honig

Los Angeles Country Sheriff's Department 